\title{
BOEKRECENSIE
}

\section{D.P. Engberts, Voortgezette verkenning: de saamhorigheid van medische ethiek en gezondheidsrecht ${ }^{*}$}

\author{
Prof. mr. J.C.J. Dute*
}

Op 15 september 2017 heeft Dick Engberts met de rede 'Voortgezette verkenning: de saamhorigheid van medische ethiek en gezondheidsrecht' afscheid genomen als hoogleraar in de normatieve aspecten van de geneeskunde aan de Universiteit Leiden. Om 'de vervlochtenheid van recht en ethiek' (p. 4) te laten zien bespreekt hij eerst een aantal (bekende) arresten, zoals Liefdehuis, Lindenbaum-Cohen en Gouden kronen en stifttanden. Vervolgens behandelt hij twee thema's: de anonimiteit van spermadonoren (voor de inwerkingtreding van de Wet donorgegevens kunstmatige bevruchting (WDKB) in 2004) en de positie van minderjarigen.

Wat het eerste thema betreft pleit hij voor 'de erkenning door het recht van een morele norm, inhoudende dat mensen er aanspraak op kunnen maken te weten wie hun biologische ouders zijn, althans dat niemand hen daarvan mag afhouden als die afstamming op zichzelf bekend is' (p. 9). Naar mijn oordeel wordt die norm door het recht al erkend, zij het dat de wetgever ook rekening heeft gehouden met de gerechtvaardigde verwachtingen van donoren vóórdat de WDKB tot stand kwam. Waarom aan dat belang geen gewicht mag toekomen, maakt Engberts niet duidelijk. Dat 'in laatste instantie het de ethiek is die, ook ten aanzien van het recht, de plaats opeist die haar was onthouden' (p. 9) zegt mij in dit verband niet veel.

* D.P. Engberts, Voortgezette verkenning: de saamhorigheid van medische ethiek en gezondheidsrecht, afscheidsrede, Universiteit Leiden.

** Jos Dute is hoogleraar gezondheidsrecht aan de Radboud Universiteit Nijmegen en lid van de redactie van dit tijdschrift.
Wat de positie van minderjarigen betreft passeert een vijftal casus de revue, waarbij er tussen de betrokken partijen (ernstig ziek kind, ouders, behandelaars) geen overeenstemming wordt bereikt over het te voeren beleid en de rechter eraan te pas moet komen om de knoop door te hakken. Het in de WGBO neergelegde beslissysteem ten aanzien van minderjarigen (vanaf twaalf tot zestien jaar toestemming van zowel ouders als kind, tenzij het kind wilsonbekwaam is) kan de goedkeuring van Engberts wegdragen, 'zij het dat de toepassing ervan nadere aanvulling behoeft vanuit de ethiek.' Hij bepleit vervolgens dat uitgangspunt moet blijven dat wilsonbekwaamheid niet mag worden afgeleid uit de inhoud van de te nemen beslissing.

Engberts stelt verder dat, in plaats van het hanteren van de term wilsonbekwaamheid, beter kan worden teruggekeerd naar de oorspronkelijke, in de wet neergelegde omschrijving, te weten dat iemand niet in staat kan worden geacht tot een redelijke waardering van zijn belangen ter zake. Die omschrijving dwingt ertoe om in concrete gevallen te benoemen wat 'een redelijke waardering' is en wat 'zijn belangen ter zake' zijn. Verder zou er bij minderjarigen 'soms sprake kunnen zijn van asymmetrische verhoudingen' (p. 15), waarvoor in het recht meer oog zou moeten zijn. Wat Engberts daarmee bedoelt, is me niet helemaal duidelijk geworden, behalve dan dat meer moet worden gekeken naar de 'details' van de casus en de 'concrete omstandigheden en verhoudingen' (p. 15).

Wat verscholen (in noot 11) stelt Engberts: 'De thematisering van de verhouding recht - ethiek is teleurstellend in zowel het toonaangevende gezondheidsrechtelijke handboek als in een veel gebruikt 
leerboek over medische ethiek (...).' Dat moge zo zijn - hij werkt deze stelling verder niet uit -, met de rede van Engberts komen we op dit onderwerp ook niet echt verder. Maar wie (zoals ik) houdt van zijn geheel eigen, welbespraakte stijl, komt met dit afscheidscollege zeker wel aan zijn trekken. 